\title{
Board Characteristics and Sustainability Reporting of Listed Non-Financial Firms in Nigeria
}

\author{
Ajepe Ayobami Oluwatoyin*, Samuel Eniola Agbi, Lateef Olumide Mustapha \\ Department of Accounting, Nigerian Defence Academy, Kaduna, Nigeria \\ Email address: \\ ayobamiajepe@nda.edu.ng (A. A. Oluwatoyin) \\ ${ }^{*}$ Corresponding author \\ To cite this article: \\ Ajepe Ayobami Oluwatoyin, Samuel Eniola Agbi, Lateef Olumide Mustapha. Board Characteristics and Sustainability Reporting of Listed \\ Non-Financial Firms in Nigeria. Journal of Finance and Accounting. Vol. 9, No. 5, 2021, pp. 182-189. doi: 10.11648/j.jfa.20210905.11
}

Received: August 15, 2021; Accepted: August 30, 2021; Published: September 15, 2021

\begin{abstract}
The hazardous effects of companies' activities have sparked the increasing need from stakeholders for transparent and trustworthy report on sustainability issues. There is still evidence of low report on sustainability performance in the listed non-financial firms in Nigeria which has attributed to corporate governance mechanism issues. Therefore, this study examines the effect of board characteristics on sustainability reporting of listed non-financial firms in Nigeria from 2010 to 2018. Sustainability reporting was measured using content analyses on corporate annual report on sustainability used Global Reporting Initiatives (G4) guidelines. The population of the study consist of 47 non-financial firms from Consumer goods, Industrial and Oil and Gas sectors. The study used a sample of 30 firms and secondary data which was employed, sourced from the audited annual report of the sampled firms was employed. Robust Fixed effect regression was used for the analysis and the study found among others that board gender has positive and significant effect on sustainability reporting of listed nonfinancial firms in Nigeria. The study concludes that women directors enhance the level of reporting on sustainability reporting of listed non-financial firms in Nigeria. The study recommendation among others that board of directors should ensure diversity gender by appointing more women directors on the board as the mean also reveal that their presence is low.
\end{abstract}

Keywords: Board Characteristics, Sustainability Reporting, Non-financial Firms

\section{Introduction}

The demands from corporate organization have gone beyond the maximization of the shareholder's wealth to the need of other stakeholders of the firms which includes the employee, community and the environment [49]. This is as a result of the effects of the firm's activities on community, employees and the environment. Hence, there is need for firms to take a wider perspective on their reports by incorporating sustainability performance information essential to meeting these goals and reducing information asymmetric [48].

Sustainability Reporting represents the report on activities of corporations that have direct impact on society, its environment, and economic performance. Sustainability reporting allows businesses to reveal their policies, objectives and results in all Economic, Governance, Social, Ethical, and Environmental (EGSEE) issues, thereby ensuring the attainment of long-term financial goals while also minimizing negative social and environmental impacts [46]. The notion is that a business must broaden its emphasis beyond making profits by taking into account the impact of its operations on the economy, society and the environment. It is a report published by a business or firm on the economic, environmental and social impacts of its day-to-day activities. Sustainability reporting also lays out the company's values, governance model and shows the connection between its policy and its commitment to a sustainable global economy.

Organizations are required now to report their sustainability performance by following proper standards for sustainability reporting, i.e. Global Reporting Initiative (GRI), Sustainability Accounting Standards Board (SASB), Carbon Disclosure Project (CDP), Task Force on Climaterelated Financial Disclosure (TCFD), etc. This aims to build trust for consumers and all stakeholders of companies [31]. It is reported that the Global Reporting Initiative (GRI) is the most widely used by companies reporting on sustainability $[34,35]$. Furthermore, the standards for GRI 
sustainability reporting require all user's organization to assess their sustainability success and to publish the findings in a similar manner to financial reporting. About 80 per cent of the world's largest businesses use principles of the Global Reporting Initiative (GRI), which guarantees accountability [5].

Baba \& Abdul-Manaf asserted that effective corporate governance is important for corporate sustainability reporting [10]. However, the corporate governance structure and process of firms holds a strategic responsibility in promoting the level of sustainability reporting, more so practicing good corporate governance within an enterprise will in many ways contribute to better reporting on sustainability. Corporate governance is seen as the combination of various mechanisms which stem from Internal to External mechanisms. This includes the board of directors, audit committee and ownership structure. The board of directors is seen as an internal control mechanism with the ability to monitor and control management action. A large size of board improves transparency and encourage management to disclose more information to the stakeholders [17].

There has been increase in demand by regulators and others stakeholders for trustworthy information on environmental, social and economic (ESE) performance of the firms as a result of the degrading environmental effects of corporate organization activities to human and environment over the years [40]. Increase natural disasters, carbon emissions, as well as pollution problems (water and air) and social inequalities, have become a major global problem [36; 14]. In terms of industrialization and globalization, these disasters are considered the potential repercussions of poor sustainability practices [6].

Report on substantiality practice in some non-financial firms in Nigeria is low [42]. Using Global reporting initiative disclosure check list (GRI-G4 reporting guidelines), they reported that the report on sustainability practice by the industrial goods firms such as Lafarge, Dangote Cement and the rest of the firms on average where $15 \%$. Prior before [42, 7] observe that sustainability reporting in Oil and Gas firms in Nigeria is deficient. Accountability on social and environmental impact cannot be ignore as they are essential to meeting others stakeholders needs aside the shareholders. [1] Attributes low reports on sustianability performance in Nigeria to ineffective and poor corporate govenance practice by firms. Corporate governance mechanisms such as the board of directors are not sustainability compliance [11]. According to [15] and [39], corporate governance is essential for sustainable business practices in Nigeria. A good corporate governance mechanism in terms of the board of directors will enable companies to place priority on innovations that are environmentally friendly and sustainable [37].

To date, numerous studies have been carried out to empirically evaluate the influence of board of directors on sustainability in developed countries such as [40] in Australia, [9] in France. Furthermore, the larger part of the studies has focused only on the environmental aspects of sustainability, without considering the economic and social aspects [19,2].

In terms of Domain, studies in Nigeria focus mostly on Oil and gas firms of which this study expand its scope by including others sectors as sustainability reporting is required from all firms especially industrial and consumer goods firms who are into manufacturing activities. The outcome of the study will assist organizations management and board of directors in determining how corporate governance affects sustainability reporting. It will help regulatory authorities like Security and Exchange Commission (SEC), Financial Reporting Council of Nigeria (FRCN) etc. in enhancing their understanding of board on the extent of firm sustainability reporting and the level of sustainability reported by sampled firms and to guide them in making decisions and policies that will encourage sustainability reporting. Hence, this study aim to investigate the effect of board characteristics on sustainability reporting of listed non-financial firms in Nigeria. This paper proceed as follows section 2 will focus literature and theoretical foundation, section 3 will anchor the methodology of the work, section 4 will deal with result and discussion on analysis while the final section 5 will give the conclusion and recommendation.

\section{Literature Review}

In the literature, sustainability reporting has been introduced as "reporting on how an organization contributes or aims to contribute in the future, to the improvement or deterioration of economic, environmental and social conditions, developments, and trends at the local, regional or global level" [24]. The aim of a sustainability report is to provide adequate information to stakeholders to hold the organization's sustainability performance accountable. Sustainability reporting is the mechanism through which sustainability information pertaining to firms' sustainability performance is conveyed to the stakeholders of firms [27, 47] According to [16], sustainability report is referred to as the level to which the report provides valid and reliable data to satisfy information needs of stakeholders, more so the decision-model used by stakeholders to assess the organization, and the recorded data is a credible and accurate measure of the sustainability success dimensions used in that model. [12] Defined sustainability reporting as information provided in the company's annual report on its activities, programs and use of resources deemed to affect both the general public and the group of stakeholders concerned. In addition, sustainability report also presents the organizational value and governance model and shows the link between its strategy and its commitment to sustainable global economy [25]. In a generic word, sustainability report is defined as any media transmitting information about an organization's sustainability performance to its stakeholders.

In the development of sustainability reporting a number of standards and guidelines are crucial. These guidelines were described by [38] as originating from the Carbon Disclosure Project (CDP); the International Organization for Standards (ISO), the Global Reporting Initiative (GRI), 
the Greenhouse Gas Protocol, the United Nations Global Compact, Account-Ability principles and other consultants, are also responsible for ensuring sustainability disclosures and reporting. The study adopts definition of sustainability reporting by [26]. GRI is a leading corporate reporting agency with a goal to encourage the use by government, business and non-profit organizations of sustainability reporting; thereby adding to sustainable growth. GRI's most recent reporting principles and standard disclosures (G4) were released in July 2013 [23].

The theory of stakeholders is based on the supposition that shareholders are not the only party with a stake in a company. Stakeholder theory claimed that consumers or clients, suppliers and local communities often have an interest in a business. They can influence the company's success or failure. Managers also have special responsibilities to ensure that all stakeholders (not only shareholders) earn a fair return on their business investment [22]. Stakeholder theories called for some form of sustainability report that applies to the environment, social and economic is an obligation to act in a transparent manner, even if that means a reduction in a company's long-term income [33].

Strong board mitigates these challenges from a stakeholder's point of view by ensuring sustainability coverage in their interactions with stakeholders through annual or integrated reports, stand-alone sustainability reports and corporate social responsibility reports, blogs, and brochures. As indicated by [25] and [35], sustainability reporting is growing rapidly, and researchers such as [20] and [16] noted that, this is due to various pressure from stakeholder groups. It is in reality the board of directors that decides on the concept of the company's responsibility, thereby impacting the sustainability reports submitted to stakeholders. From the Stakeholder perspective, having the non-executive director's members on the board of directors' structure will help to secure investors interest [8, 29]. As a representative of stakeholder, nominated non-executive officers are seen as a mechanism for controlling management behavior [21].

From an agency theory perspective, [51] evaluated the impact of board size on the sustainability disclosure of 100 publicly listed companies in Malaysia. The study discovered that the size of the board has a significant impact on the disclosure of sustainability. Another study in an Asia country by [52] assessed the impact of board size on disclosures on fiscal, social, and environmental sustainability. The research adopted an explanatory approach to the mixed sequential methods. Data on board size and disclosure of sustainability were collected from the top 100 companies listed on the Pakistan Stock Exchange (PSE) for the period 2012-2015. Overall, their results indicate that elements of the CG boost disclosures of sustainability. The study concluded that a large board size is better able to monitor and control management decisions on sustainability issues (either economic, environmental, or social) and have resulted in a better disclosure of sustainability. [2] In Nigeria evaluated the effect of board size on corporate environmental reporting from the agency theory perspective. The study makes use of a sample of 24 non-financial companies from 2011 to 2015 encompassing three sectors, that is, industrial goods, natural resources and oil \& gas. The study employed panel data technique and confirmed that board size does not influence corporate environmental reporting. This study is limited as it concentrated only on environmental reporting aspect of sustainability with no attention to economic, social reporting. [45] Assessed the effect of board size on environmental disclosure in Jordan using a sample of 63 listed industrial companies and panel data were obtained from their annual report from 2014 to 2017 . The regression result revealed that large board size has a positive impact on the level of environmental disclosure. They concluded that firm with larger board disclosed more on environmental disclosure. However, the study limits its disclosure only on environmental aspect whilst sustainability reporting encompass more also include both social and economic impact.

Solabomi and Uwalomwa looked at the effects of board independence on Corporate Social and Environmental Disclosure (CSED) among Nigerian listed companies [50]" A judgmental sampling technique was used to select forty firms for the study. Data for the study were provided by a content analysis of information in the selected companies' corporate annual reports and websites for the period 2006-2010. CSED was measured using 50 information items and the study found that the proportion of non-executive directors influenced CSED positively. The study concluded that nonexecutive directors enhances firms' disclosure on a wider range of information to stakeholders which includes social and environmental information. In Indonesia, [20] studied the impact of board independence on environment disclosure practice. The research utilised a sample of 38 listed mining companies on Indonesia stock Exchange for the individual year 2012. They found confirmation that proportion of independent director on the board is insignificantly related to the extent of environmental disclosure. Similarly, [40] examined the impact of board independence on sustainability reporting by examining firms in Australia's Resources industry. The study investigated the influence of total disclosures on the three aspects of sustainability disclosures which are environmental, economic and social. The study provided evidence that of a significant and positive impact of board independence on sustainability disclosures. These findings presented empirical evidence to support firms with greater board independence supporting more efficient corporate governance offering a greater degree of sustainability disclosures.

Also, [43] examined the effect of board independence on the sustainability reporting level of listed companies in Sri Lanka. The level of sustainability reporting has been assessed according to GRI G4 guidelines. The study examined the effect of board independence using regression analysis. The study found that the proportionate effect of independent directors on voluntarily practiced reporting of sustainability disclosures is significant. The study concluded that board 
independence has a positive impact on the level of sustainability reporting of listed Sri Lankan companies. [30] Conducted a study of board independence and sustainability disclosure in Singapore. The study used a cross-sectional data on a sample of 462 firms in 2016. They employed regression analysis to examine the relationship between sustainability disclosure and board independence. The finding showed that firm with independent directors are more likely to engage in sustainability reporting. Board independence positively influences the firm's reporting probability on sustainability in Singapore. The finding of the study is similar to [2] who provide evidences that board independence enhances corporate environmental reporting.

"Baalouch, Atadi and Hussainey conducted a study with a focus on board's independence on it relationship environment (environmental performance, degree of pollution of the company) of listed French companies [9]" The study used a sample of 570 firms, year observation for six (6) years period from 2009 to 2014. This study developed a self-constructed index to measure environmental disclosure quality based qualitative characteristic of IASB and GRI frameworks in line with [13]. The study employed a panel data analysis. The study confirmed that independent directors has negative and significant impact on environment disclosure. The study also found evidence that quality of disclosure remains relatively low. They concluded that board independence adversely influences environment disclosure. On the contrary, [44] study disclosed that board independence does not influence the level of environmental disclosure.

Al-Shaer and Zaman examined the influence of board gender diversity on sustainability reporting using a sample of 333 firms listed in UK FTSE350 in 2012 [3]. The study found evidence that gender diverse boards are associated with higher quality sustainability reports and independent female directors have greater effect on sustainability reporting quality than male directors. They concluded that female directors improve sustainability reporting. [4] Carried out a study on the influence of corporate board diversity on sustainability reporting on a sample of quoted manufacturing firms in Nigeria. The study focused on conglomerates, consumer goods, and, industrial goods sector. They employed fixed effects panel regression and measured sustainability reporting using an Economic, Social, and Governance (ESG) index. They found that the women directors significantly improve sustainability reporting. They concluded that women directors improve the firm's reports on sustainability. This is similar to the study by [40], who found the board gender improve sustainability reporting.

Adeniyi and Fadipe Investigated the effect of board gender on sustainability reporting in among brewery manufacturing firm [1]. They used a sample of four brewery firms for two years' period from 2015 to 2016 . They study used regression analysis and found that board gender diversity does not significantly affect sustainability reporting. They concluded that board gender does not influence sustainability reporting. However, the study used a sample for four firms for two years' period which is not enough for generalization. [32]
Examined the effect of board gender on firm's sustainability practices in Malaysia. The study used a sample of 38 listed firms from 2010 to 2016 . They found that women director negatively related with firm sustainability practice. They concluded that female directors adversely affect sustainability practice. Another study in Malaysia by [18], assessed the influence of gender on the extent and quality of sustainability reporting among the top 100 Malaysian listed companies. This study found that the average proportion of women directors out of the total number of board members is $17 \%$. From there regression result, they found that having women board members significantly impact the firm sustainability reporting. They concluded that women directors have a different way of perception, thinking, and ideas that could influence companies' sustainability initiative and reporting. [42] evaluated the impact of gender diversity on firms' sustainability responsiveness in Nigeria This study explored female engagement from three major platforms, namely women as directors, management team leaders, and female workforce using a sample of 10 banks from the period 2013-2016. The study employed GRI 4 and discovered that female directors had an adverse and insignificant influence on sustainability reporting. They concluded that gender diversity was not the major driving force behind the sustainability reporting of the sampled banks in Nigeria.

\section{Methodology}

The study population is made up of forty-seven (47) nonfinancial firms of consumer goods, industrial and oil and gas sectors in the Nigerian Stock Exchange. There are twelve (12) listed oil and gas firms, fourteen (14) firms in the Industrial Goods sector and twenty-one (21) firms in the Consumer Goods sector listed in the floor of Nigeria stock exchange as at $31^{\text {st }}$ December, 2018 (NSE, 2018). Based on the stratified sampling criteria the sample size of 30 firms which comprises 7 companies in the oil and gas sector, 9 firms in the industrial goods sector and 14 firms in the consumer goods sector. The 30 firms represent $65 \%$ (47) of the population which is good enough to make inference.

Data was collected from the annual report and sustainability reports of selected non-financial firms from (oil $\&$ gas, industrial goods and consumer's goods sectors) listed on the Nigeria Stock Exchange for the period under review. The annual reports for the period 2010-2018 was used as a result of increased awareness and stakeholder pressure within those periods. The dependent variable, sustainability reporting, is measured with un-weighted disclosure index that is recognized in line with GRI to gauge the informational content. Therefore, sustainability reporting index of a firm is calculated using the equation below:

$$
\mathrm{SRI}=\sum \frac{\text { number of sustianbility disclosure }}{\text { MAX sustaianbilty disclosure }}
$$

Where:

SRI = Sustainability Reporting Index

MAX SRI = Maximum Sustainability Reporting 
disclosure (140).

All six variables of interest will be regress using the Sustainability Reporting disclosures (GRI G4), a dependent variable. The following model was developed and will be tested:

$$
\mathrm{SRI}_{\mathrm{it}}=\beta_{0}+\beta_{1} \mathrm{BSIZE}_{\mathrm{it}}+\beta_{2} \mathrm{BI}_{\mathrm{it}}+\beta_{3} \mathrm{BG}_{\mathrm{it}}+\beta_{4} \mathrm{FZ}_{\mathrm{it}}+\mathrm{e}_{\mathrm{it}}
$$

Where:

SRI = Sustainability Reporting Index (GRI G4 Disclosure) BSIZE = Board Size, BI = Board Independence, $\mathrm{BG}=$ Board Gender, FSZ $=$ Firm size, $\beta_{0}=$ Constant, $\beta_{1 \ldots} \beta_{4}=$ Coefficients, $\mathrm{i}=$ cross-sectional script $(\mathrm{i}=30) \mathrm{t}=$ time series script $(\mathrm{t}=8), \mathrm{e}=$ error term.

Table 1. Descriptive Statistic.

\begin{tabular}{llllll}
\hline Variables & Obs & Mean & Std dev. & Min & Max \\
\hline SR & 270 & .37 & .06 & .3 & .5 \\
BSIZE & 270 & 9.9 & 3.09 & 4 & 19 \\
BI & 270 & .63 & .13 & .2 & .81 \\
BG & 270 & .14 & .11 & 0 & .43 \\
FSZ (million) & 270 & 117151.1 & 213199.0 & 176.726 & 1502564 \\
\hline
\end{tabular}

Descriptive Statistic from STATA, 2020.

Table 2 reveals the description on the variables of study. The dependent variable, Sustainability reporting (SR) has a mean value of .37, a standard deviation of .06 . This shows that there is a low dispersion of the variable from their mean. The mean value suggests that on average value the level of sustainability report based on G4 guideline during the period of the study for the non-financial firms in Nigeria is $37 \%$. Also, Table 2 further shows that board size (BSIZE) has a mean value of approximately 10 members. This shows that the average size of the board of the sample firms during the period of the study is 10 board members. In addition, Table 2 reveals that the mean value of the board independence is .63 with a standard deviation of 0.13 . With regard to $B G$ the mean value is .14 . This signifies that on average $14 \%$ of the sample firm's board member are female. This implies that there was low proportion of female on the board during the period of the study.

Table 2. Multicollinearity Test.

\begin{tabular}{lll}
\hline Variables & VIF & Tolerance Value \\
\hline BSIZE & 1.58 & 0.63 \\
BI & 1.01 & 0.99 \\
BG & 1.08 & 0.92 \\
FSZ & 1.51 & 0.66 \\
Mean VIF & 1.30 & \\
\hline
\end{tabular}

Source: VIF result from STATA 13, 2020.

The premise of the OLS regression model is that there is no strong association between the explanatory variables (absence of multicollinearity). Furthermore, the findings in Table 2 indicate that there is no dangerous association as the highest variance inflation factor (VIF) is 1.58 the rule of thumb for the Tolerance Value and Variance inflation factor (VIF) is any value greater than 0.1 (TV) and VIF value less than 10. [28] Suggest no multicollinearity.
Table 3. Diagnostic and Hausman Specification Tests.

\begin{tabular}{lll}
\hline & Chi-square & Prob \\
\hline Jacque Bera & 5.04 & 0.081 \\
Breusch- Pagan or cook - Weisberg to test & 4.41 & 0.040 \\
Hausman Specification test & 17.32 & 0.002 \\
\hline
\end{tabular}

Source: VIF result from STATA 13, 2020.

Assumption of Linear regression model entails that the error terms should be normally distributed. The normality of the data and residual was test using Jacque Bera test at 5\% level of significant. The residual reveal an insignificant Pvalue of 0.081 which is greater than $5 \%$ level of significance. This implies that the residual is normal distributed. Further OLS regression presumed the variance of the error terms is constant (homoskedastic). If these criteria are not fulfilled, the estimators are skewed and can't be used to make any inferences. Heteroscedasticity test was performed to account for a regression model's expectation of homoscedasticity. Table 3 shows that the study employs the Breusch- Pagan or cook - Weisberg test which displays a chi ${ }^{2}$ is 4.41 and the prob $>\mathrm{chi}^{2}$ is 0.04 which is less than $5 \%$ level of significance. This point that the residual is heteroscedastic. The study interpreted a robust standard error regression as a way of dealing with the heteroscedastic issue. Hausman specification test was conducted to determine if the effect is random or fixed. The result in Table 2 displays prob $>\mathrm{chi}^{2}$ of 0.001 which is significant $5 \%$ level. This significant P-value shows that Hausman test favors fixed effect model. This suggests that fixed effect is more idea for the study. Thus, the study interpreted robust fixed effect regression.

Table 4. Fixed Effect Regression Model.

\begin{tabular}{lllll}
\hline Variable & Coefficients & Robust Std error & T-value & P-value \\
\hline BSIZE & .01 & .00 & 4.51 & $0.000^{*}$ \\
BI & .08 & .02 & 4.65 & $0.000^{*}$ \\
BG & .08 & .01 & 5.15 & $0.000^{*}$ \\
FSZ & .13 & .03 & 4.20 & $0.000^{*}$ \\
CONST & -.09 & .13 & -0.71 & 0.482 \\
R $^{2}$ Within & .24 & & & \\
F-stat & 37.01 & & & \\
p-value & 0.000 & & & \\
\hline
\end{tabular}

*significant a $5 \%$ level of significance.

$$
\mathrm{SR}=-.09+.01 \mathrm{BSIZE}+.08 \mathrm{BI}+.08 \mathrm{BG}+.13 \mathrm{FSZ}+\mathrm{e}
$$

\section{Interpretation of the Results}

Table 4 presents the result of the fixed effect regression result selected for the study. The $\mathrm{R}^{2}$ is reveals a value of .24 indicating that the board of director's variables and the control variable firm size are able to explain the variations in sustainability of the listed firms to a tune of $24 \%$ while the remaining percentage is explained by other factors not captured in the model. The f-statistic chi square shows a value of 37.01 with associated P-value of 0.000 which is less than $5 \%$ level of significance indicating that the board of director's variables have joint effect on sustainability reporting of listed non-financial firms in Nigeria. It also 
divulges that the model is adequate and fit.

Board Size and Sustainability Reporting. Table 4 reveals that board size has a positive coefficient of .01 and a p-value of 0.000 which is significant at less than $5 \%$ level of significance. This implies that board size has positive and significant effect on sustainability reporting of listed nonfinancial firms in Nigeria. This suggests that any increase in the size of the board members will improve the level of sustainability reporting of listed non-financial firms in Nigeria by .01. This signifies that board size has great role to play in improving sustainability reporting of listed nonfinancial firms in Nigeria. This also implies that larger board size is better able to check and control management decisions regarding sustainability issues. This finding is in line with a priori expectation of the study, also in line with the stakeholder theory. It is also in line with prior studies by [53, $52,44]$ and so forth who found evidence that larger board size will increase sustainability reporting and contrary to [51, 2] and so forth who discovered that board size does not influence sustainability reporting.

Board Independence and Sustainability Reporting. In addition, Table 4 shows that board independence has a coefficient of .08 and a P-value of 0.000 which is significant at $5 \%$ level of significance. This suggests that an independent director has positive and significant effect on sustainability reporting. This finding signifies that any increase in the proportion of the non-executive directors on the board will increase sustainability reporting by .09 . This further implies that addition to non-executive director on the board will promotes more effective corporate governance that will enhance extent of sustainability reporting. It also indicated as the non-executive directors who have less stake in the firm will work in a way that the goal of the shareholders and other stakeholders are satisfy. The finding also conforms to the priori expectations of the study of a positive effect between board independence and sustainability reporting and also the stakeholder's theory used to underpin the study. It further supports the works of $[41,44,31]$ and so forth. It is contrary to the works of [9] who found an adverse relationship and also [45, 20], who found no relationship.

Board Gender and Sustainability Reporting. Further Table 4 demonstrates that board gender has a positive coefficient of .08 and a p-value of 0.000 which is less than $5 \%$ level of significance. This shows that board gender has positive and significant effect on sustainability reporting of the firms. The finding suggests that any addition $\mathrm{n}$ to the proportion of women on the board will improve sustainability reporting by .08. This implies that when the sampled firms increase the proportion of women representation on the board, it bring about improvement in sustainability reporting as women are seen to be more ethical and more selfless in their duties. This finding is in conformity with Stakeholders theory that suggests that female directors are more likely to be stakeholder oriented, concerned about ethical practices and socially responsible behavior and also be inclined to take actions to reduce perceived risks The finding is in line with $[3,4,41]$ who found out that female directors improve on sustainability and contrary to [1] and [42] who found evidence that female participant on the board does not affect sustainability reporting.

\section{Conclusion and Recommendation}

This study examined the effect of board characteristics on sustainability reporting of listed non-financial firms in Nigeria for the period 2010 to 2018. The specific objectives include examine the effect of board size on sustainability reporting of listed non-financial firms in Nigeria, evaluate the effect of board independence, assess the effect of board gender on sustainability reporting of listed non-financial firms in Nigeria, after review on the discussion of findings the study concludes that the size of the board plays a significant role in improving sustainability reporting of listed non-financial firms in Nigeria. Furthermore, the study concludes that the independence of the board of directors will enhance the sustainability reporting of listed non-financial firms in Nigeria and that female directors will improve the level of sustainability reporting of listed non-financial companies in Nigeria. In line with the findings and the conclusions of this study, the following recommendations were made. The study recommends that the board of directors of the non-financial firms in Nigeria should comply with the new Nigeria Code of Governance 2018 demands that takes a wider perspective. The board should be reasonable in size so as to fulfil their sustainability reporting demands by the new code. Further, the non-executive directors of the listed non-financial firms in Nigeria should be made more effective, through training and expertise improvement in order to improve the quality of sustainability reporting. Also, the board of directors should increase the proportion of women representation on the board reckoning that the mean reflects a low proportion of women in the listed non-financial firms in Nigeria.

\section{References}

[1] Adeniyi, S. I., \& Fadipe, A. O. (2018). Effect of Board Diversity on Sustainability Reporting in Nigeria: A Study of Beverage Manufacturing Firms. Indonesian Journal of Corporate Social Responsibility and Environmental Management, 1 (1), 43-50.

[2] Aliyu, U. S. (2019). Board characteristic and corporate environmental reporting in Nigeria. Asian Journal of Accounting Research. 4 (1), 2019, 2-17, DOI 10.1108/AJAR09-2018-0030.

[3] Al-Shaer, H., \& Zaman, M. (2016). Board Gender Diversity and Sustainability Reporting Quality. Journal of Contemporary Accounting \& Economics, 12 (3), 210-222. http://doi.org/10.1016/j.jcae.2016.09.001

[4] Anazonwu, H. O., Egbunike, F. C. \& Gunardi, A. (2018). Corporate Board Diversity and Sustainability Reporting: A Study of Selected Listed Manufacturing Firms in Nigeria. Indonesian Journal of Sustainability Accounting and Management, 2 (1), 65-78. 
[5] Anderson, S. (2019). Top 5 reasons why sustainability reporting is relevant to every business. https://www.bizjournals.com/sanfrancisco/news/2019/06/01/to p-5-reasons why- sustainability-reporting-is.html

[6] Ansong, A. (2017). Corporate social responsibility and access to finance among Ghanaian SMEs: The role of stakeholder engagement. Cogent Business and Management, 4 (1), 1385165. https://doi.org/10.1080/ 23311975.2017.138516

[7] Asaolu, T. O., Agboola, A. A., Ayoola, T. J., \& Salawu, M. K. (2011). Sustainability reporting in the Nigerian oil and gas sector. In: Environmental Management Conference, Federal University of Agriculture, Abeokuta, Nigeria, 12-15 September 2011, pp: 1-24. Retrieved from http://scholar.oauife.edu.ng/sites/default/files/tjayoola/files/23 8-475-1-sm.pdf

[8] Arayssi, M., Dah, M., \& Jizi, M. (2016). Women on boards, sustainability reporting and firm performance. Sustainability Accounting. Management and Policy Journal, 7 (3), 376-401.

[9] Baalouch, F., Ayadi, S. D., \& Hussainey, K. (2019). A study of the determinants of environmental disclosure quality: evidence from French listed companies. Journal of Management and Governance, 23: 939-971 https://doi.org/10.1007/s10997-019-09474-013

[10] Baba, B. U. \& Abdul-Manaf, K. B. (2017). Board Governance Mechanisms and Sustainability Disclosure: A Moderating Role of Intellectual Capital. Asian Journal of Multidisciplinary Studies, 5 (10), 163-189.

[11] Babalola, A., \& Adedipe, O. A. (2014). Corporate governance and sustainable banking sector : evidence from Nigeria. Research Journal of Finance and Accounting, 5 (12), 32-44.

[12] Chan, M. C., Watson, J. \& Woodliff, D. (2014). Corporate governance quality and CSR disclosure. Journal of Business Ethics, 125, 59-73.

[13] Chauvey, J. N., Giordano-Spring, S., Cho, C., \& Patten, D. M. (2014). The normativity and legitimacy of the csr disclosure: evidence from France. Journal of Business Ethics, 130 (4), 789-803.

[14] Chong, K. (2019). Pasir Gudang chemical pollution - What harm can these chemicals do to you? | SoyaCincau. com. In Soyacincau. Retrieved from https://www. soyacincau.com/2019/03/16/pasir-gudang-chemicalpollution/

[15] Comyns, B. (2016). Determinants of GHG reporting: an analysis of global oil and gas companies. Journal of Business Ethics, 136 (2): 349-369. https://doi.org/10.1007/s10551-014 2517-9

[16] Daub, C. H. (2007). Assessing the quality of sustainability reporting: an alternative methodological approach. Journal of Cleaner Production, 15 (1), 75-85.

[17] Darus, F., Mad, S., \& Yusoff, H. (2014). The Importance of Ownership Monitoring and Firm Resources on Corporate Social Responsibility (CSR) of Financial Institutions. Procedia - Social and Behavioral Sciences, 145, 173-180.

[18] Dembo, A. M., \& Rasaratnam, S. (2015). Corporate governance and sustainability practices : Evidence from Nigeria. In International Conference on Accounting Studies 1-13. Johor Bahru, MALAYSIA: ISSAD.

[19] Dibia, N. O., \& Onwuchekwa, J. C. (2015) Determinants of environmental disclosures in Nigeria: a case study of oil and gas companies. International Journal of Finance and Accounting, 4 (3), 145-152.

[20] Dissanayake, D., Tilt, C., \& Xydias-Lobo, M. (2016). Sustainability reporting by publicly listed companies in Sri Lanka. Journal of Clean Production, 129: 169-182. https://doi.org/10.1016/j.jclepro.2016.04.086

[21] Dixon, R., Mousa, G. A., \& Woodhead, A. (2005). The role of environmental initiatives in encouraging companies to engage in environmental reporting. European Management Journal, 23 (6), 702-716.

[22] Donaldson, T., \& Preston, L. E. (1995). The stakeholder theory of the corporation: Concepts, evidence, and implications. Academy of Management Review, 20: 65-91.

[23] Global Reporting Initiative (2013). Sustainability reporting guidelines version G4. Retrieved from http://www.globalreporting.org/resourcelibrary/GRIG4- Part1Reporting- Principles-and Standard-Disclosures.pdf

[24] Global Reporting Initiative (GRI). (2015). GRI's History. GRI Newsletter. https://www.globalreporting.org/infor mation/about- gri/grihistory/Pages/GRI\%27 shistory. aspx

[25] Global Reporting Initiative GRI. (2016). GRI sustainability reporting 2016 sustainability performance. CRODA GRI Report Achive. https://www.croda.com/en $\mathrm{gb} /$ sustainability/gri-report/grireport- archive

[26] GRI (n.d) https://www.globalreporting.org/information/sustainabilityreporting/Pages/default.aspx

[27] Gnanaweera, K. A. K., Kunori, N., \& Ntim, C. G. (2018). Corporate sustainability reporting: Linkage of corporate disclosure information and performance indicators. Cogent Business and Management, 5 (1), 1-12. https://doi.org/10.1080/23311975.2018.1423872

[28] Gujarati, D. (2004) Basic Econometics. $4^{\text {th }}$ Edition, McGrawHill Companies, New York.

[29] Gul, F. A., Srinidhi, B., \& Ng, A. C. (2011). Does board gender diversity improve the informativeness of stock prices? Journal of Accounting and Economics, 51, 314338.

[30] Meibo, H., \& Lawrence L. (2018). Board governance and sustainability disclosure: a cross-sectional study of Singaporelisted companies, Sustainability, 10, 2578; doi: $10.3390 / \mathrm{su} 10072578$.

[31] Incorp (2019). Why sustainability reporting is important for business in Singapore, retrieved from https://www.incorp.asia/learn/why-sustainability-reporting-isimportant-for- businesses-in-Singapore/

[32] Ismail, A. M. \& Latiff, Z. H. M. (2019). Board Diversity and Corporate Sustainability Practices: Evidence on Environmental, Social and Governance (ESG) Reporting. International Journal of Financial Research, 10 (3), 31-50.

[33] Jones, T. A., Freeman, \& Wicks, R. E. (2002). Stakeholder theory: The state of art. N. Bowie, Ed. The Blackwell Guide to Business Ethics. Blackwell Publishing, Oxford, U.K., 19-37.

[34] KPMG. (2015). Currents of change: The KPMG survey of corporate responsibility reporting 2015. http://www.kpmg.com/au/en/issuesandinsights/articlespublication s/pages/corporate-responsibility-reporting-survey -2013.aspx 
[35] KPMG (2017). The road ahead: The KPMG Survey of Corporate Responsibility Reporting 2017. KPMG [online] vailable at:

https://assets.kpmg/content/dam/kpmg/xx/pdf/2017/10/kpmgsurvey-of-corporate-responsibility-reporting-2017.pdf.

[36] Manning, B., Braam, G., \& Reimsbach, D. (2019). Corporate governance and sustainable business conduct-effects of board monitoring effectiveness and stakeholder engagement on corporate sustainability performance and disclosure choices. Corporate Social Responsibility and Environmental Management, $26 \quad$ (2), 351-366. https://doi.org/10.1002/csr.1687

[37] Micah, L. C., \& Umobong, A. A. (2013). Corporate governance and sustainable development in Nigeria: a study of oil companies in the Niger delta region. International Journal of Business and Management, 8 (7), 127-132. http://doi.org/10.5539/ijbm.v8n7p127

[38] Muller, S. (2011). Quantitative sustainability disclosure - An international comparison and its impact on investor valuation (Master's Thesis). Lappeenranta University of Technology, Finland. Retrieved from: http://www.doria.fi/bitstream/handle/10024/69887/nbnfife201 106101728.pdf?sequence $=2$

[39] Nigeria code of corporate governance (2018). Retrieved from: https://nambnigeria.org/Nig_Code_of_Corp._Governance_20 18.pdf

[40] Nigeria Stock Exchange (2019). NSE GRI host sustainability reporting workshop. Retrieved from: http://www.nse.com.ng/mediacenter/pressreleases/Pages/NSEGRI-Host- Sustainability-Reporting-Workshop.aspx

[41] Ong, T., \& Djajadikerta, H. D. (2017) Impact of corporate governance on sustainability reporting: empirical study in the Australian resources industry. School of Business and Law, Edith Cowan University, Australia.

[42] Owolabi, F., Taleatu, A., Adetula, D. \& Uwuigbe, U. (2016). Assessment of Sustainability Reporting in Nigerian Industrial Goods Sector. $3^{\text {rd }}$ international conference on Africa Development Issue. 383-386.

[43] Ozordi, E. Eluyela, D. F., Uwuigbe, U., Uwuigbe, O. R. \& Nwaze, C. E (2020). Gender diversity and sustainability responsiveness: evidence from Nigerian fixed money deposit banks. Problems and Perspectives in Management, 18 (1), 119-129. doi: 10.21511/ppm.18(1).2020.11.
[44] Pramodhya, B. T. A., Uppala, S. H., Lolitha E. E. A., Gayan D. D. M., \& Anuradha R. K. A. (2018). Impact of corporate governance on level of sustainability reporting of Sri Lankan listed companies. Journal of Accounting and Business Research, 1 (1).

[45] Rabi, A. M. (2019). Board characteristics and environmental disclosure: evidence from Jordan. International Journal of Business and Management; 14 (2), 57-65, https://doi.org/10.5539/ijbm.v14n2p57

[46] Rezaee, Z. (2015). Business Sustainability: Performance, Compliance, Accountability and Integrated Reporting. Sheffield, UK: Greenleaf Publishing Limited.

[47] Schaltegger, S., \& Wagner, M. (2006). Integrative management of sustainability performance, measurement and reporting. International Journal of Accounting, Auditing and Performance Evaluation, 3 (1), 1. https://doi.org/10.1504/IJAAPE.2006.010098.

[48] Simnett, R.; Vanstraelen, A. \& Chua, W. F. (2009). Assurance on Sustainability Reports: An International Comparison. Account. Rev, 84, 937-967.

[49] Sousa Filho, J. M. de, Wanderley, L. S. O., Gómez, C. P., \& Farache, F. (2010). Strategic corporate social responsibility management for competitive advantage. BAR - Brazilian Administration Review, 7 (3), 294-309. doi: 10.1590/s18.

[50] Solabomi, O. A., \& Uwalomwa, U. (2013). Effects of corporate governance on corporate social and environmental disclosure among listed firms in Nigeria. European Journal of Business and Social Sciences, 2 (5), 76-92, http://www.ejbss.com/recent.aspx

[51] Spangenberg, J. (2005). Economic sustainability of the economy: constructs and indicators. International Journal of Sustainable Development, 8 (12), 47-64. http://dx.doi.org/10.1504/IJSD.2005.007374

[52] Tamoi, J., Faizah, D., Mustaffa M. Z., \& Yussri, S. (2014). Does good corporate governance lead to better sustainability reporting? an analysis using structural equation modeling. Procedia - Social and Behavioral Sciences, 145: 138- 145.

[53] Zeeshan, M., Rehana K., Waris, A., Zabair, A., \& Tahira, S. (2018). Does corporate governance affect sustainability disclosure? A mixed methods study. Sustainability 2018, 10 (207): doi: 10.3390/su10010207. http://www.mdpi.com/journal/sustainability. 